EPIDEMIOLOGY

\title{
Is childhood immunisation associated with atopic disease from age 7 to 32 years?
}

\author{
Kazunori Nakajima, Shyamali C Dharmage, John B Carlin, Cathryn L Wharton, Mark A Jenkins, \\ Graham G Giles, Michael J Abramson, E Haydn Walters, John L Hopper
}

Thorax 2007;62:270-275. doi: 10.1136/thx.2006.062547

See end of article for authors' affiliations

Correspondence to

Dr S Dharmage, Department of Public Health, Centre for Molecular, Environmental, Genetic and Analytic Epidemiology, School of Population Health, The University of Melbourne, Level 2, 723 Swanston Street, Carlton, VIC 3053

Australia; s.dharmage@

unimelb.edu.au

Received 19 March 2006 Accepted

15 September 2006

Published Online First

7 November 2006
Background: There is ongoing conjecture over whether childhood immunisation leads to an increased risk of developing atopic diseases.

Objective: To examine associations between childhood immunisation and the risk of atopic disease. Method: Immunisation histories of 8443 Tasmanian children born in 1961 obtained from school medical records were linked to the Tasmanian Asthma Study. Associations between immunisation status and atopic diseases were examined while adjusting for possible confounders using multiple logistic regression.

Results: Diphtheria immunisation was weakly associated with an increased risk of asthma by age 7 years (odds ratio (OR) 1.3, 95\% confidence interval (CI) 1.1 to 1.7), but there was no evidence of any association for four other vaccinations studied. An increased risk of eczema by age 7 years was associated with immunisation against diphtheria (OR $1.5,95 \% \mathrm{Cl} 1.1$ to 2.1 ), tetanus (OR $1.5,95 \% \mathrm{Cl}, 1.1$ to 2.0 ), pertussis (OR $1.5,95 \% \mathrm{Cl} 1.1$ to 1.9) and polio (OR $1.4,95 \% \mathrm{Cl} 1.0$ to 1.9 ) but not small pox. Similar but slightly weaker patterns of association were observed between the risk of food allergies and immunisation against diphtheria (OR 1.5, 95\% Cl 1.0 to 2.1), pertussis (OR 1.4, 95\% Cl 1.1 to 1.9), polio (OR 1.4, 95\% Cl 1.00 to 2.1) and tetanus (OR $1.3095 \% \mathrm{Cl} 0.99$ to 1.70 ), but not with small pox. There was no evidence of associations between immunisation history and hay fever, or incidence of later-onset atopic outcomes.

Conclusions: The few effects seen in this study are small and age-dependent, and nearly all our findings support numerous previous studies of no effect of vaccines on asthma. Based on these findings, the fear of their child developing atopic disease should not deter parents from immunising their children, especially when weighed against the benefits.
$M$ ore than a quarter of children have some manifestation of atopic (allergic) disease, and the prevalence of such diseases worldwide, especially in "westernised" countries, has risen dramatically in the past few decades. ${ }^{1-3}$ Much has been written theorising that infants who are exposed to frequent infections may develop a $\mathrm{T}$ helper (TH) 1-predominant rather than a $\mathrm{TH} 2$-predominant immune system, thereby decreasing the risk of atopic diseases. The global increase in the prevalence of atopic disease has thus been hypothesised to be attributed to either an increased use of vaccines with a subsequent reduction in infectious diseases, or to a direct immune-potentiating effect of vaccines. Further fuelling parental concerns are reports that most childhood asthma diagnoses are made before the age of 5 years, ${ }^{45}$ corresponding to the period in which children are usually immunised.

Several studies have been conducted on pertussis vaccine, as it is a potent stimulus for IgE production. ${ }^{6-8}$ Some report no association $^{9-11}$ with atopic disease, whereas others report an increased risk, ${ }^{12}$ and some report that it is protective. ${ }^{13-15}$ Similarly, conflicting evidence has been reported for other vaccines including diphtheria, tetanus and polio. ${ }^{10}{ }^{13} 16-18$ However, none of the studies have found any harmful effect for measles, ${ }^{10121319}$ BCG $^{20-22}$ and smallpox vaccine ${ }^{2324}$ on the development of atopic diseases.

Most of these studies generally had lack of power, misclassification of retrospectively collected immunisation data or incomplete adjustment for potential confounding factors, all of which might have contributed to their inconsistent findings. The few studies that have overcome these methodological issues have reported no associations, ${ }^{25}{ }^{26}$ or a possible early protective effect. ${ }^{14}$ This inconsistency highlights the importance of investigating such associations within cohort studies that span childhood and adulthood.

In this paper, we report an analysis of associations between immunisation history and the development of asthma and atopic diseases in a cohort born in a single year followed from 7 years of age for three subsequent decades.

\section{METHODS}

\section{Study design}

The Tasmanian Asthma Study is a prospective populationbased cohort study which started in 1968 (fig 1). All children who were born in 1961 and attended primary schools in Tasmania (hereafter termed probands) were eligible, and 8583 (99\%) participated. ${ }^{27}$ Parents were asked to complete questionnaires regarding the sociodemographic characteristics, lifestyle factors and medical history of the probands, with particular attention to symptoms and/or physician diagnosis of asthma and other atopic diseases.

In 1974, a questionnaire was administered to all probands who were still at school in Tasmania, and $7484(87.2 \%$ of the original cohort) participated. In 1991, 1000 probands who had asthma by age 7 years and 1000 probands who did not have asthma by age 7 years were randomly selected from the original sample. A total of 1763 probands were traced and 1501 responded to a postal survey $(74.7 \%)$.

Parent-completed school medical records were available for $8443(98.3 \%)$ of the total cohort of probands, and these formed the main dataset for the current analysis. Data were scanned. School medical records were available for 7334 (98\%) of the 7484 children who participated in the 1974 (age 13 years) follow-up, and for 1465 (98.1\%) of the 1494 people who participated in the 1991 (age 30 years) follow-up. 


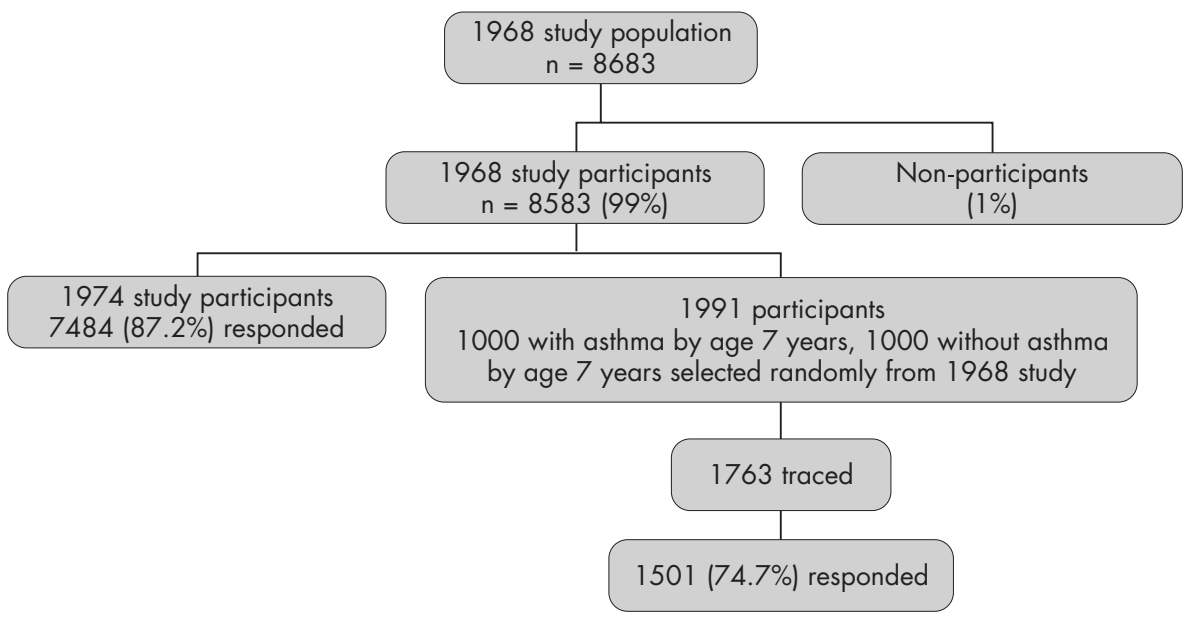

Figure 1 Flow diagram of the Tasmanian Health Study follow-up studies.

Parent-reported vaccination status of diphtheria, tetanus, pertussis, polio and smallpox was unavailable for $2.2 \%, 2.4 \%$, $2.4 \%, 2.5 \%$ and $2.2 \%$, respectively, of the total cohort.

\section{Data collection}

Information regarding the outcomes of interest (asthma and other atopic conditions) was extracted from the 1968 survey, and the 1974 and 1991 follow-up studies. The outcomes were: (1) having ever had each of the atopic conditions (asthma or wheezy bronchitis, eczema, food allergies and hay fever) by age 7 years, as recorded in the 1968 study; (2) having ever had asthma or wheezy bronchitis by age 13 years, as recorded in the 1974 study (in 1968 and 1974, proband asthma and other atopic conditions were reported by parents, whereas in 1991 the probands themselves reported this information); and (3)"lateonset atopic disease" (late-onset asthma was defined as reporting not having had asthma or wheezy bronchitis by age 13 years, but reporting having had it by age 30 years; as the information on eczema, food allergy and hay fever was not collected in 1974, late-onset eczema, food allergy and hay fever were defined as not having had these diseases by age 7 years but having had them by age 30 years). The comparison groups for these late-onset atopic outcomes comprised individuals who had not developed asthma by age 13 years, and not developed eczema, food allergy or hay fever by age 7 years.

The main exposures of interest were immunisations against diphtheria, tetanus, pertussis, polio and smallpox. Immunisation data were obtained from the children's school medical records completed by their parents. These records have collected data on immunisation against diphtheria, pertussis, tetanus, poliomyelitis and smallpox using specific questions.

Data on potential confounders of the association between immunisation and atopic disease were extracted from the 1968 survey and school medical records. These included the sex of the child, birthplace and feeding in the first 3 months after birth (bottle-fed only, bottle and breast-fed, breast-fed only), parental asthma and smoking and maternal employment, probands' birth order, any past bacterial infections (diphtheria, pertussis), pneumonia and any past viral infections (measles, mumps, rubella and chicken pox) among probands.

\section{Data analysis}

Odds ratios (ORs), with $95 \%$ confidence intervals and p values, for associations between immunisation status and outcomes were estimated using multiple logistic regression. Effect modification due to family history of atopic disease was examined by stratification and inclusion of interaction terms.
Potential confounders were included and their effect assessed. The best model was identified by conducting likelihood ratio tests between nested models, with and without each potential confounder. Variables were retained in the final model if the likelihood ratio test for their inclusion indicated $p<0.15$. To account for the random stratified sampling used in the 1991 study, the associations between immunisation status and lateonset eczema, food allergy and hay fever were examined while stratifying by the sampling variable (asthma status in 1968). If the relevant associations were similar across strata, the sampling variable was then included in multivariate analysis of the association between immunisation status and these outcomes.

\section{RESULTS}

At age 7 years, $87.2 \%(n=7314)$ of the probands had been immunised against diphtheria, $85.8 \% \quad(\mathrm{n}=7187)$ against tetanus, $85.6 \%(\mathrm{n}=7172)$ against pertussis, $88.9 \%(\mathrm{n}=7450)$ against polio and $13.6 \%(\mathrm{n}=1142)$ against smallpox. The correlation between immunisation against diphtheria, tetanus, pertussis and polio was high ( $\kappa$ ranged from 0.5 to 0.9 ).

\section{Immunisation and participant characteristics}

Table 1 describes the participant characteristics and the cumulative prevalence of reported atopic diseases. Information on the age at onset of atopic diseases and dates of immunisation were not available.

Some participant characteristics were closely associated with immunisation status. Children born in the UK, US, New Zealand, Canada or South Africa were more likely to have been immunised against diphtheria, pertussis and polio than those born in Tasmania (ORs ranged from 1.7 to 2.0; all $\mathrm{p}<0.01$ ). On the other hand, those born in other countries were less likely to be immunised against pertussis and tetanus (ORs ranged from 0.3 to $0.6 ; \mathrm{p}<0.05$ ). One exception was smallpox vaccine, with those born anywhere outside of Australia being much more likely to have been immunised compared with those born in Tasmania (OR $=33 ; \mathrm{p}<0.001)$. Within Australia, those born in other states were 2.5 -fold more likely to have been immunised against smallpox than those born in Tasmania $(\mathrm{p}<0.001)$.

Children who were exclusively breast-fed in the first 3 months of life were more likely to have been immunised against diphtheria, tetanus, pertussis and polio than those who were exclusively bottle-fed (ORs from 1.5 to 1.8 ; all $\mathrm{p}<0.001$ ). Similarly, children with a history of viral infections (ORs ranged from 1.3 to $1.4 ; \mathrm{p}<0.001$ ) and first-born children (ORs ranged from 1.3 to $1.4 ; \mathrm{p}<0.001$ ) were more likely to have been 


\begin{tabular}{|c|c|}
\hline Participant characteristics & $\mathrm{n}(\mathrm{N} ; \%)$ \\
\hline \multicolumn{2}{|l|}{ Sex } \\
\hline Female & $4014(8215 ; 49)$ \\
\hline \multicolumn{2}{|l|}{ Birthplace } \\
\hline Tasmania & $7396(8179 ; 90.4)$ \\
\hline Other states in Australia & $480(8179 ; 5.9)$ \\
\hline $\begin{array}{l}\text { UK, US, NZ, Canada, or South } \\
\text { Africa }\end{array}$ & $237(8179 ; 3.0)$ \\
\hline $\begin{array}{l}\text { Arrica } \\
\text { Other }\end{array}$ & $66(8179 ; 0.1)$ \\
\hline \multicolumn{2}{|l|}{ Feeding in the first 3 months } \\
\hline Bottle-fed only & $2327(8142 ; 28.6)$ \\
\hline Bottle-fed + breast-fed & $2620(8142 ; 32.2)$ \\
\hline Breast-fed only & $3195(8142 ; 39.2)$ \\
\hline \multicolumn{2}{|l|}{ Parental smoking in 1968} \\
\hline Neither parents smoke & $2291(7291 ; 31.4)$ \\
\hline Father smokes & $2404(7291 ; 33.0)$ \\
\hline Mother smokes & $593(7291 ; 8.1)$ \\
\hline Both mother and father smoke & $2003(7291 ; 27.5)$ \\
\hline \multicolumn{2}{|c|}{ Parental asthma in 1968} \\
\hline Neither parents have/had asthm & $5929(7395 ; 80.2)$ \\
\hline Father has/had asthma & $661(7395 ; 8.9)$ \\
\hline Mother has/had asthma & $674(7395 ; 9.1)$ \\
\hline Both parents have/had asthma & $131(7395 ; 1.8)$ \\
\hline Mother employed in $1968^{*}$ & $1699(7634 ; 22.2)$ \\
\hline First-born child & $2330(8054 ; 28.9)$ \\
\hline Any past bacterial infection $\dagger$ & $1428(8167 ; 17.5)$ \\
\hline Any past viral infection $\ddagger$ & $6570(8169 ; 80.0)$ \\
\hline Any history of pneumonia & $812(8179 ; 9.9)$ \\
\hline Any history of pertussis & $719(8173 ; 9.0)$ \\
\hline Had asthma by age 7 years & $1319(8215 ; 16.1)$ \\
\hline Had asthma by age 13 years & $1717(7436 ; 23.1)$ \\
\hline Had eczema by age 7 years & $783(8126 ; 9.6)$ \\
\hline Had food allergy by age 7 years & $564(8158 ; 6.9)$ \\
\hline Had hay fever by age 7 years & $1032(8193 ; 12.6)$ \\
\hline
\end{tabular}

immunised against diphtheria, tetanus, pertussis and polio. First-born children were also 1.6-fold more likely to have been immunised against smallpox $(\mathrm{p}<0.001)$. Children whose both parents smoked were less likely to have been immunised against diphtheria, tetanus and polio than those whose neither parent smoked (ORs from 0.5 to 0.6 ; all $\mathrm{p}<0.001$ ). Children who had a history of bacterial infection before age 7 years were less likely to have had all the immunisations investigated in the study (ORs from 0.6 to 0.7 ; all $\mathrm{p}<0.001$ ). Parental asthma and maternal employment were not associated with immunisation levels (all $\mathrm{p}>0.05$ ).

\section{Immunisation and atopic disease by ages 7 and 13 years}

There was little evidence for an association between any immunisation and asthma by ages 7 or 13 years (table 2). However, immunisation against diphtheria, tetanus, pertussis and polio were all associated with an increased risk of having eczema and food allergy by age 7 years. This effect seemed to be more consistent for eczema. Furthermore, diphtheria and pertussis vaccines were also associated with an increased risk of hay fever by age 7 years. Effect modifications of the associations between immunisation and asthma, food allergy or eczema by parental asthma were absent (all $\mathrm{p}>0.05$ ).

Table 3 summarises the results of the multiple logistic regression analysis of the associations between immunisation and atopic diseases by ages 7 and 13 years. The analysis was adjusted for potential confounding by sex, birthplace, history of bacterial infection, parental smoking, parental asthma, history of viral infection, birth order and history of pneumonia. After adjustment, there was substantially stronger evidence for a positive association between diphtheria immunisation and risk of asthma by age 7 years and a slightly weaker association with risk of asthma by age 13 years. The change in estimates was due to a negative confounding effect of bacterial infection and parental smoking. None of the other vaccines was clearly associated with having asthma by ages 7 or 13 years, although ORs for tetanus and pertussis were $>1$, possibly reflecting the fact that these vaccines are very often given in conjunction with diphtheria.

Adjustment for confounders made little difference to the estimated associations between diphtheria, tetanus, pertussis, polio vaccine and the combination of diphtheria, tetanus and pertussis and increased risk of eczema, nor to the associations between food allergies and immunisations for diphtheria, pertussis and polio.

\section{Immunisation and late-onset atopic disease by age 30 years}

Of the 753 subjects who did not have asthma by age 7 years, 55 (7\%) developed asthma by age 13 years. Of the 698 who remained free of asthma by age 13 years, 81 (11\%) developed asthma by age 30 years. Univariate analysis showed that diphtheria, pertussis, tetanus and polio immunisations were generally associated with a lower risk of developing asthma after age 13 years, with the strongest evidence for negative association between immunisations against pertussis $(\mathrm{OR}=0.55 ; 95 \% \quad \mathrm{CI} \quad 0.30$ to $1.00 ; \mathrm{p}=0.05)$ and polio ( $\mathrm{OR}=0.45 ; 95 \%$ CI 0.21 to $0.95 ; \mathrm{p}=0.04$ ). For those who did not have asthma by age 7 years, the cumulative incidences of eczema, food allergy and hay fever from age 7 to 30 years were $9.2 \%, 17.9 \%$ and $37.3 \%$, respectively. Among those who had asthma by age 7 years, the cumulative incidences of eczema, food allergy and hay fever from age 7 to 30 years were $11.3 \%$, $21.5 \%$ and $49.4 \%$, respectively. None of the immunisations was associated with onset of other atopic diseases after age 7 years. After adjustment for confounders, there remained little evidence for an association between immunisation status and late-onset asthma or atopic diseases (table 4), with, if anything, a tendency for lower risk of late-onset asthma and eczema among those immunised against diphtheria, pertussis, tetanus and polio.

\section{DISCUSSION}

This seems to be the first prospective cohort study examining the association between multiple immunisations in childhood and atopic outcomes up to the age of 30 years. We found that diphtheria immunisation was weakly associated with a small increase in reporting of having asthma by age 7 years. However, none of the other immunisations was associated with an increased risk of asthma. A modestly higher reported incidence of eczema and food allergies by age 7 years was associated with immunisation against diphtheria, tetanus, pertussis and polio but not with smallpox. There was no evidence of associations between immunisation and hay fever, or incidence of lateronset atopic outcomes.

Our findings are consistent with the large number of studies ${ }^{10252829}$ which found no associations between asthma and immunisations like DTP, measles, pertussis and rubella. The exception in our study, the diphtheria vaccine, supports one previous study which reported that immunisation against diphtheria, pertussis, tetanus and polio was a risk factor for having had asthma before age 10 years. ${ }^{16}$ However, there are conflicting reports regarding the association between pertussis 
Table 2 Cumulative prevalence of childhood atopic diseases by vaccination status, with crude odds ratio comparing those immunised with those not immunised

\begin{tabular}{|c|c|c|c|c|}
\hline & Non-immunised $\mathbf{N}(\%)^{*}$ & Immunised N (\%)* & OR for disease OR $(95 \% \mathrm{Cl})$ & $\mathrm{p}$ Value \\
\hline \multicolumn{5}{|c|}{ Asthma by age 7 years } \\
\hline Diphtheria & 1032 (14.2) & 7135 (16.3) & $1.17(0.98$ to 1.41$)$ & 0.09 \\
\hline Tetanus & 1148 (15.3) & 7007 (16.2) & $1.07(0.90$ to 1.27$)$ & 0.47 \\
\hline Pertussis & 1161 (14.8) & 6999 (16.3) & $1.12(0.94$ to 1.33$)$ & 0.21 \\
\hline Polio & $894(16.3)$ & $7264(16.0)$ & $0.98(0.81$ to 1.18$)$ & 0.81 \\
\hline Smallpox & $7038(16.4)$ & 1111 (14.1) & 0.84 (0.70 to 1.01 ) & 0.06 \\
\hline \multicolumn{5}{|c|}{ Asthma by age 13 years } \\
\hline Diphtheria & $903(21.8)$ & 6492 (23.2) & 1.08 (0.87 to 1.34$)$ & 0.49 \\
\hline Tetanus & $997(21.1)$ & $6386(23.2)$ & $1.13(0.90$ to 1.42$)$ & 0.27 \\
\hline Pertussis & $1010(22.1)$ & 6378 (23.2) & $1.07(0.90$ to 1.26$)$ & 0.45 \\
\hline Polio & 775 (23.2) & $6615(23.1)$ & $0.99(0.80$ to 1.24$)$ & 0.96 \\
\hline Smallpox & $6461(22.2)$ & $919(22.6)$ & $1.02(0.88$ to 1.18$)$ & 0.77 \\
\hline \multicolumn{5}{|c|}{ Eczema by age 7 years } \\
\hline Diphtheria & $1006(6.9)$ & $7073(10.2)$ & 1.51 (1.17 to 1.95$)$ & $<0.01$ \\
\hline Tetanus & $1121(7.1)$ & $6946(10.1)$ & $1.47(1.16$ to 1.88$)$ & $<0.01$ \\
\hline Pertussis & $1132(6.9)$ & $6940(10.1)$ & 1.51 (1.19 to 1.93 ) & $<0.001$ \\
\hline $\begin{array}{l}\text { Polio } \\
\text { Pa }\end{array}$ & $867(7.4)$ & 7204 (9.9) & 1.38 (1.06 to 1.80$)$ & 0.02 \\
\hline Smallpox & $6959(9.6)$ & $1102(9.4)$ & 0.98 (0.79 to 1.22 ) & 0.85 \\
\hline \multicolumn{5}{|c|}{ Food allergy by age 7 years } \\
\hline Diphtheria & $1018(5.2)$ & $7092(7.2)$ & 1.40 (1.05 to 1.87$)$ & 0.02 \\
\hline Tetanus & $1135(5.6)$ & $6963(7.1)$ & $1.30(0.99$ to 1.70$)$ & 0.06 \\
\hline Pertussis & $1147(5.1)$ & $6956(7.1)$ & $1.42(1.08$ to 1.87$)$ & 0.01 \\
\hline Polio & $882(5.3)$ & $7220(7.1)$ & 1.36 (1.00 to 1.85 ) & 0.05 \\
\hline Smallpox & $6988(6.8)$ & $1104(7.2)$ & 1.05 (0.82 to 1.34 ) & 0.70 \\
\hline \multicolumn{5}{|c|}{ Hay fever by age 7 years } \\
\hline Diphtheria & 1028 (10.2) & 7119 (13.0) & 1.31 (1.06 to 1.62$)$ & 0.01 \\
\hline Tetanus & $1145(11.3)$ & 6990 (12.9) & $1.16(0.95$ to 1.41$)$ & 0.14 \\
\hline Pertussis & 1159 (10.9) & 6981 (12.9) & $1.21(0.99$ to 1.48$)$ & 0.06 \\
\hline Polio & $892(12.4)$ & 7246 (12.6) & $1.02(0.82$ to 1.25$)$ & 0.88 \\
\hline Smallpox & 7019 (12.5) & 1110 (13.1) & 1.05 (0.87 to 1.27 ) & 0.61 \\
\hline
\end{tabular}

vaccine and the risk of asthma. ${ }^{12} 1426$ The retrospective nature of some of these studies, subsequent misclassification of exposure or outcome status, and inadequate data on confounders might have contributed to these conflicting results.

Our study provided evidence that diphtheria, tetanus, pertussis and polio immunisations were associated with approximately $50 \%$ higher risk of eczema and food allergies in 7-year-olds. We cannot conclude that the effects of these vaccines were independent of each other because of the overlap in use between vaccines. Our findings are consistent with those from a previous study that found associations between wholecell pertussis vaccine and atopic diseases such as eczema and hay fever up to the age of 12 years. ${ }^{12}$ In contrast, another longitudinal study found that rubella and pertussis vaccines were associated with a decreased risk of atopic dermatitis and allergic sensitisation levels in 5 -year-olds. ${ }^{14}$

In our study, children immunised against diphtheria, pertussis, tetanus and polio had a somewhat lower risk of late-onset asthma and eczema, especially for pertussis vaccine. These findings suggest that certain vaccines produce agedependent effects on the development of atopic disease, indicating that biological mechanisms underlying some earlyonset atopic diseases may differ from those for the late-onset atopic diseases.

First-born children in this study were more likely to have been immunised. This offers a possible alternative explanation for the effect of family size and/or number of siblings on the risk of developing atopic diseases, as noted by previous studies. ${ }^{20}{ }^{30}$ Previously, this has been attributed to the hygiene hypothesis, with older children not having the benefit of endotoxin and viral exposures from siblings.
Some strengths of our study include its prospective design and lack of selection bias. Both the original study and the follow-up at age 13 years were representative of the population as the participation rates for the two surveys were high $(98.9 \%$ and $87.2 \%$, respectively). ${ }^{27}{ }^{31}$ The responses to the 1991 questionnaire was similar for those with and those without childhood asthma $(74.1 \% \vee 75.3 \%)$, and for men $(73.7 \%)$ and women $(76.0 \%)$, showing no evidence of response bias. ${ }^{32}$

A major limitation of our study was that immunisation data would have been subject to recall error, given that they were obtained from school medical records completed by parents after children started schooling. Parents of children with allergies/asthma might have either recalled the immunisation status better or wrongly classified their children as having been immunised. Such differential misclassification could have exaggerated the observed association between immunisation and allergies and asthma. The use of parental reporting of atopic conditions is another limitation, as it is likely to be less reliable than physician reporting. Only the question used to define asthma has been validated against physician diagnosis. ${ }^{33}$

Furthermore, parental health attitudes might have affected both seeking a diagnosis of an atopic condition and having their children vaccinated, which might also have contributed to the risk of atopic conditions being associated with vaccination. Such a detection bias is more likely with eczema, given that eczema is more likely to develop in early childhood, during which timeframe childhood immunisations are given. The observed associations may also suggest that there is a higher likelihood of childhood immunisations in those already at greater risk of atopic disease. However, this is an unlikely explanation for observed associations, as parental asthma was 
Table 3 Association between immunisation and childhood atopic diseases: ORs adjusted for sex, birthplace, history of bacterial infection, parental smoking, parental asthma, history of viral infection, birth order and history of pneumonia

\begin{tabular}{|c|c|c|c|}
\hline Outcome & Vaccine & OR $(95 \% \mathrm{Cl})$ & p Value \\
\hline $\begin{array}{l}\text { Asthma by age } \\
7 \text { years }\end{array}$ & $\begin{array}{l}\text { Diphtheria } \\
\text { Tetanus } \\
\text { Pertussis } \\
\text { Polio } \\
\text { Smallpox }\end{array}$ & $\begin{array}{l}1.33(1.06 \text { to } 1.68) \\
1.16(0.94 \text { to } 1.43) \\
1.19(0.96 \text { to } 1.47) \\
1.05(0.83 \text { to } 1.32) \\
0.94(0.75 \text { to } 1.19)\end{array}$ & $\begin{array}{l}0.01 \\
0.16 \\
0.11 \\
0.69 \\
0.62\end{array}$ \\
\hline $\begin{array}{l}\text { Asthma by age } \\
13 \text { years }\end{array}$ & $\begin{array}{l}\text { Diphtheria } \\
\text { Tetanus } \\
\text { Pertussis } \\
\text { Polio } \\
\text { Smallpox }\end{array}$ & $\begin{array}{l}1.28(0.98 \text { to } 1.66) \\
1.18(0.89 \text { to } 1.55) \\
1.11(0.91 \text { to } 1.37) \\
1.03(0.79 \text { to } 1.35) \\
1.08(0.90 \text { to } 1.29)\end{array}$ & $\begin{array}{l}0.07 \\
0.24 \\
0.31 \\
0.84 \\
0.39\end{array}$ \\
\hline $\begin{array}{l}\text { Eczema by age } \\
7 \text { years }\end{array}$ & $\begin{array}{l}\text { Diphtheria } \\
\text { Tetanus } \\
\text { Pertussis } \\
\text { Polio } \\
\text { Smallpox }\end{array}$ & $\begin{array}{l}1.53(1.13 \text { to } 2.07) \\
1.53(1.15 \text { to } 2.04) \\
1.46(1.10 \text { to } 1.93) \\
1.36(1.00 \text { to } 1.87) \\
0.95(0.73 \text { to } 1.23)\end{array}$ & $\begin{array}{l}<0.01 \\
<0.01 \\
<0.01 \\
0.05 \\
0.69\end{array}$ \\
\hline $\begin{array}{c}\text { Food allergy by } \\
\text { age } 7 \text { years }\end{array}$ & $\begin{array}{l}\text { Diphtheria } \\
\text { Tetanus } \\
\text { Pertussis } \\
\text { Polio } \\
\text { Smallpox }\end{array}$ & $\begin{array}{l}1.47(1.04 \text { to } 2.07) \\
1.26(0.93 \text { to } 1.71) \\
1.39(1.01 \text { to } 1.91) \\
1.44(1.00 \text { to } 2.07) \\
1.18(0.88 \text { to } 1.58)\end{array}$ & $\begin{array}{l}0.03 \\
0.14 \\
0.04 \\
0.05 \\
0.28\end{array}$ \\
\hline $\begin{array}{l}\text { Hay fever by age } \\
7 \text { years }\end{array}$ & $\begin{array}{l}\text { Diphtheria } \\
\text { Tetanus } \\
\text { Pertussis } \\
\text { Polio } \\
\text { Smallpox }\end{array}$ & $\begin{array}{l}1.20(0.94 \text { to } 1.53) \\
1.05(0.84 \text { to } 1.31) \\
1.10(0.88 \text { to } 1.38) \\
0.88(0.69 \text { to } 1.12) \\
1.07(0.85 \text { to } 1.34)\end{array}$ & $\begin{array}{l}0.15 \\
0.67 \\
0.42 \\
0.30 \\
0.59\end{array}$ \\
\hline
\end{tabular}

not associated with the propensity to immunise, suggesting that parents of children with atopic diseases are unlikely to immunise their children more than the rest of the population.
Another limitation was a lack of precise dates of immunisation for all subjects and, as a consequence, the temporal relationship could not be examined for early-onset atopic diseases, especially for eczema. As immunisations are usually given in the first years of life, it is most likely that they were completed before asthma development, but we cannot be certain about this. Also, the different types of vaccines given could not be established. This was a problem when examining smallpox immunisation, where children from other countries were more likely to be immunised with different strains. In Australia, there were two forms of polio vaccine-the Salk (injected polio vaccine) was commonly used before the introduction of Sabin (oral polio vaccine) in 1966. Such differences may limit the generalisability of some findings.

In summary, our study provides evidence that some immunisation may be associated with a small increased risk of atopic disease, mostly for eczema, by age 7 years; the evidence for an association with asthma risk was minimal. Our findings are consistent with a range of hypotheses: that immunisations may lead to increased atopic disease in early childhood, that parents who have children with allergies recall their children having had immunisation better than other parents, and/or that parental health attitudes may have affected both seeking a diagnosis of an atopic condition and having their children vaccinated. None of these immunisations seemed to be associated with the incidence of late-onset atopic disease, with, if anything, reduced rates of atopic disease among those immunised (clearest with pertussis vaccine and eczema).

In this study, the few effects seen were small and agedependent, the general prevalence of atopic disease was low $(<10 \%)$ and nearly all the findings of this study support numerous previous studies of no effect of vaccines on asthma. Based on these findings, the fear of their child developing atopic disease should not deter parents from immunising their children, especially when weighed against the benefits.

Table 4 Association between immunisation status and reporting asthma after the age of 13 years and other atopic diseases after the age of 7 years: ORs adjusted for confounders as listed

\begin{tabular}{|c|c|c|c|}
\hline Outcome/vaccine & OR $(95 \% \mathrm{Cl})$ & p Value & Confounders \\
\hline \multicolumn{4}{|l|}{ Asthma } \\
\hline Diphtheria & $0.58(0.26$ to 1.27$)$ & 0.17 & \multirow[t]{5}{*}{ Sex, parental asthma } \\
\hline Tetanus & $0.79(0.32$ to 1.96$)$ & 0.61 & \\
\hline Pertussis & $0.57(0.30$ to 1.09$)$ & 0.09 & \\
\hline Polio & $0.50(0.22$ to 1.10$)$ & 0.08 & \\
\hline Smallpox & $0.91(0.50$ to 1.65$)$ & 0.76 & \\
\hline \multicolumn{4}{|l|}{ Eczema } \\
\hline Diphtheria & $0.68(0.36$ to 1.29$)$ & 0.24 & \multirow{5}{*}{$\begin{array}{l}\text { Age } 7 \text { years asthma status, sex, } \\
\text { parental asthma, parental } \\
\text { smoking }\end{array}$} \\
\hline Tetanus & $0.76(0.38$ to 1.52$)$ & 0.44 & \\
\hline Pertussis & $0.57(0.35$ to 0.93$)$ & 0.03 & \\
\hline Polio & $0.76(0.39$ to 1.48$)$ & 0.43 & \\
\hline Smallpox & $1.20(0.79$ to 1.85$)$ & 0.39 & \\
\hline \multicolumn{4}{|l|}{ Food allergy } \\
\hline Diphtheria & $1.50(0.81$ to 2.79$)$ & 0.20 & \multirow{5}{*}{$\begin{array}{l}\text { Age } 7 \text { years asthma status, sex, } \\
\text { parental smoking }\end{array}$} \\
\hline Tetanus & $0.98(0.54$ to 1.75$)$ & 0.94 & \\
\hline Pertussis & $0.88(0.57$ to 1.35$)$ & 0.55 & \\
\hline Polio & 1.02 (0.57 to 1.83 ) & 0.94 & \\
\hline Smallpox & $1.29(0.91$ to 1.82$)$ & 0.15 & \\
\hline \multicolumn{4}{|l|}{ Hay fever } \\
\hline Diphtheria & $1.19(0.75$ to 1.89$)$ & 0.45 & \multirow{5}{*}{$\begin{array}{l}\text { Age } 7 \text { years asthma status, sex, } \\
\text { parental smoking, feeding in } 1 \text { st } \\
3 \text { months }\end{array}$} \\
\hline Tetanus & 1.09 (0.67 to 1.78$)$ & 0.72 & \\
\hline Pertussis & $0.96(0.67$ to 1.38$)$ & 0.83 & \\
\hline Polio & $0.78(0.47$ to 1.28$)$ & 0.32 & \\
\hline Smallpox & $0.98(0.73$ to 1.33$)$ & 0.91 & \\
\hline
\end{tabular}




\section{ACKNOWLEDGEMENTS}

The 1968 and 1974 studies were funded by the Tasmanian Asthma Foundation and the 1991 study was funded by the National Health Medical Research Council. Computerisation of the 1974 study was funded by the Victorian Asthma Foundation. Researchers declare that their work was independent of these funding bodies.

Researchers acknowledge Jill Waters and the Tasmanian State Archives for providing the access to past records of the study participants.

\section{Authors' affiliations}

Kazunori Nakajima, Shyamali C Dharmage, John B Carlin, Cathryn L Wharton, Mark A Jenkins, John L Hopper, Centre for Molecular, Environmental, Genetic and Analytic Epidemiology, School of Population Health, The University of Melbourne, Melbourne, Victoria, Australia Graham G Giles, Cancer Epidemiology Centre, Cancer Council Victoria, Melbourne, Victoria, Australia

Michael J Abramson, Department of Epidemiology and Preventive Medicine, Monash University, Melbourne, Victoria, Australia E Haydn Walters, Cardio Respiratory Research Group, University of Tasmania, Hobart, Australia

Competing interests: None declared.

Ethics approval: Ethics approval for the study was granted by the Human Research Ethics Committee, The University of Melbourne, Melbourne, Victoria, Australia.

\section{REFERENCES}

1 Anonymous. Worldwide variation in prevalence of symptoms of asthma, allergic rhinoconjunctivitis, and atopic eczema: ISAAC. Lancet 1998;351:1225-32.

2 Magnus $P$, Jaakkola J. Secular trends in the occurrence of asthma among children and young adults: critical appraisal of repeated cross sectional surveys. BMJ 1997;314:1795-9.

3 Peat J, van den Berg R, Green W. Changing prevalence of asthma in Australian children. BMJ 1994;308:1591-6.

4 Sears $M$, Burrows B, Flannery $E$, et al. Relation between airway responsiveness and serum lgE in children with asthma and in apparently normal children. N Engl J Med 1991;325:1067-71.

5 Platts-Mills T, Sporik R, Chapman M, et al. The role of domestic allergens. Ciba Novartis Found Symp 1997;206:173-85.

6 Mark A, Biörkstén B, Granström M. Immunoglobulin E and $G$ antibodies two years after a booster dose of an aluminium-adsorbed or a fluid DT vaccine in relation to atopy. Pediatr Allergy Immunol 1997:8:83-7.

7 Hedenskog S, Biörkstén B, Blennow $M$, et al. Immunoglobulin E response to pertussis toxin in whooping cough and after immunization with a whole-cell and an acellular pertussis vaccine. Int Arch Allergy Appl Immunol 1989;89:156-61.

8 Duchén $K$, Granström M, Hedenskog S, et al. Immunoglobulin E and $G$ responses to pertussis toxin in children immunised with adsorbed and non-adsorbed whole cell pertussis vaccines. Vaccine 1997;15:1558-61.

9 Henderson J, North K, Griffiths M, et al. Pertussis vaccination and wheezing illnesses in young children: a prospective cohort study. BMJ 1999;318:1173-6.
10 DeStefano F, Gu D, Kramarz P, et al. Childhood vaccinations and the risk of asthma. Pediatr Infect Dis J 2002;21:498-504.

11 Wickens K, Crane J, Kemp T, et al. A case-control study of risk factors for asthma in New Zealand children. Aust N Z J Public Health 2001 ;25:44-9.

12 Faroogi I, Hopkin J. Early childhood infection and atopic disorder. Thorax 1998;53:927-32.

13 Anderson H, Poloniecki J, Strachan D, et al. Immunization and symptoms of atopic disease in children: results from the International Study of Asthma and Allergies in Childhood. Am J Public Health 2001;91:1126-9.

14 Grüber C, Illi S, Lau S, et al. Transient suppression of atopy in early childhood is associated with high vaccine coverage. Pediatrics 2003;111:e282-8.

15 Bernsen RM, de Jongste JC, van der Wouden JC. Lower risk of atopic disorders in whole cell pertussis-vaccinated children. Eur Respir J 2003;22:962-4.

16 Kemp T, Pearce N, Fitzharris $P$, et al. Is immunization a risk factor for childhood asthma or allergy? Epidemiology 1997;8:678-80.

17 McKeever TM, Lewis SA, Smith C, et al. Vaccination and allergic disease: a birth cohort study. Am J Public Health 2004;94:985-9.

18 Benke G, Abramson M, Raven J, et al. Asthma and vaccination history in a young adult cohort. Aust N Z J Public Health 2004;28:336-8.

19 Lewis S, Britton J. Measles infection, measles vaccination and the effect of birth order in the aetiology of hay fever. Clin Exp Allergy 1998;28:1493-500.

20 Aaby $\mathbf{P}$, Shaheen S, Heyes $C$, et al. Early BCG vaccination and reduction in atopy in Guinea-Bissau. Clin Exp Allergy 2000;30:644-50

21 Grüber C, Meinlschmidt G, Bergmann R, et al. Is early BCG vaccination associated with less atopic disease? An epidemiological study in German preschool children with different ethnic backgrounds. Pediatr Allergy Immunol 2002;13:177-81

22 Grüber C, Kulig M, Bergmann R, et al. MAS-90 Study Group. Delayed hypersensitivity to tuberculin, total immunoglobin $E$, specific sensitization, and atopic manifestation in longitudinally followed early Bacille-Calmette-Guerinvaccinated and non-vaccinated children. Pediatrics 2001;107:e36.

23 Bager $\mathbf{P}$, Westergaard T, Rostgaard K, et al. Smallpox vaccination and the risk of allergy and asthma. J Allergy Clin Immunol 2003;111:1227-31.

24 Frey S, Newman F, Cruz J, et al. Dose-related effects of smallpox vaccine. N Engl J Med 2002;346:1275-80.

25 Nilsson L, Kjellman N, Björkstén B. A randomized controlled trial of the effect of pertussis vaccines on atopic disease. Arch Pediatr Adolesc Med 1998; 152:734-8.

26 Odent $M$, Culpin E, Kimmel T. Pertussis vaccination and asthma: is there a link? JAMA 1994;272:592-3.

27 Jenkins $M$, Hopper J, Flander $L$, et al. The associations between childhood asthma and atopy, and parental asthma, hay fever and smoking. Paediatr Perinat Epidemiol 1993;7:67-76.

28 Mullooly JP, Pearson J, Drew L, et al. Wheezing, lower respiratory disease and vaccination of full-term infants. Pharmacoepidemiol Drug Saf 2002;11:21-30.

29 Nilsson L, Kjellman N, Storsaeter J, et al. Lack of association between pertussis vaccination and symptoms of asthma and allergy (letters). JAMA 1996;275:760.

30 Strachan D. Hay fever, hygiene and household size. BMJ 1989;299:1259-60.

31 Giles G, Gibson H, Lickiss N, et al. Respiratory symptoms in Tasmanian adolescents: a follow up of the 1961 birth cohort. Aust N Z J Med 1984; 14:631-7.

32 Jenkins $M$, Hopper J, Bowes $G$, et al. Factors in childhood as predictors of asthma in adult like. BMJ 1994:309:90-3.

33 Jenkins MA, Clarke JR, Carlin JB, et al. Validation of questionnaire and bronchial hyperresponsiveness against respiratory physician assessment in the diagnosis of asthma. Int J Epidemiol 1996;25:609-16. 